\title{
REGIMEN MATRIMONIAL PERUANO
}

Héctor Cornejo Chávez

Bajo este mismo título, el Presbítero señor Victor Huapaya Q. ha escrito una interesante disertación para optar, en la Universidad de Navarra, España, el grado de doctor en Derecho Canónico.

Explícitamente, el autor se propone demostrar que el párrafo $2^{\circ}$ del art. 5 de la nueva Constitución del Perú permite modificar radicalmente el sistema matrimonial existente desde 1930, en el sentido de que, junto a un matrimonio civil sujeto a la regulación y jurisdicción del Estado, es ahora posible, no sólo un matrimonio canónico, sujeto a la normación jurídica de la Iglesia Católica, sino tantos otros sistemas de matrimonio como confesiones religiosas existan, igualmente sujetas, cada una, al respectivo ordenamiento jurídico (si lo tienen) (o al del Estado si no lo tuvieren, según parece inferirse de los términos de la tesis).

Complementariamente, el graduando sostiene que el artículo 316 del proyecto de nuevo Código Civil (elaborado por el autor de la presente nota en su calidad de ponente del Libro de Familia de la Comisión Reformadora del Código de 1936, aprobada por esta Comisión y ratificada por la Comisión Revisora antes de la intervención del Episcopado) recortaba el amplio campo legislable consagrado en la Constitución y aun infringía los principios en ella proclamados sobre libertad e igualdad religiosas, privacidad de las creencias y a-confesionalidad del Estado.

Sin mayor desarrollo, pero con alguna insistencia, la tesis sugiere, además, que dicha norma implicaba una intromisión indebida del Estado en una esfera de exclusiva regulación canónica.

En fin, implícita pero muy claramente a nuestro entender, el autor se esfuerza por explicar los motivos por los que el Episcopado peruano decidió intervenir formalmente en el proceso estatal de preparación del nuevo Código, exigiendo la eliminación de la norma en cuestión. 


\section{CONTENIDO Y ALCANCES DEL ARTICULO 5 DE LA CONSTITUCION}

Como se observa, la tesis fundamental del disertante reposa por entero sobre el contenido del párrafo $2^{\circ}$ del art. 5 de la Constitución de 1979, que él interpreta en un sentido y con unos alcances totalmente ajenos, a nuestro juicio, a los que tuvo en mente el legislador constitucional.

El mencionado artículo reza textualmente asi:

"El Estado protege el matrimonio y la familia como sociedad natural e institución fundamental de la Nación.

Las formas de matrimonio y las causas de separación y disolución son reguladas por la ley.

La ley señala las condiciones para establecer el patrimonio familiar inembargable, inalienable y trasmisible por herencia".

Tanto el autor de la tesis, como el director de la misma señor Fuenmayor, consideran que la expresión "las formas de matrimonio", que usó el legislador constituyente, es equívoca y ambigua, pues lo mismo puede referirse a clases de matrimonio con ordenamientos jurídicos totalmente distintos, o como accesos diversos al matrimonio - dos formas: la civil y la religiosa - pero con un único régimen jurídico matrimonial, el del Estado.

El graduando asume plenamente la primera interpretación y sobre ella construye toda su tesis. De nuestra parte, creemos que, en efecto, hay cierta equivocidad en la expresión utilizada $-\mathrm{y}$ en eso radicó una de las razones de nuestro desacuerdo con ella en el seno de la Asamblea Constituyente-; pero nos inclinamos resueltamente en el sentido de que fue la segunda la que estuvo en la mente deì legislador.

Pues bien, hay varios caminos por los cuales se puede llegar a averiguar cuál fue la intención del constituyente: el de la hermenéutica jurídica, el del iter legislativo del art. 5, y el que podríamos llamar de argumentación $a b$ absurdo. 


\section{Interpretación juridica de la expresión "formas de matri- monio"}

La mayoría -si acaso no la totalidad - de los tratadistas entiende la forma como el signo o conjunto de signos por medio de los cuales se exterioriza la voluntad de realizar un negocio jurídico; $y$ en tal sentido se ocupan de ella como uno de los elementos esenciales del acto o como uno de los requisitos de su validez.

"Forma -enseña Messineo (1) - es el medio o el modo con la que se pone en ser la declaración expresa de voluntad, o sea, es el aspecto exterior que esta última asume... La forma, por consiguiente, es un elemento indispensable que, en cierto sentido, se identifica con la declaración de voluntad, de manera que, sin una forma, la declaración de voluntad no podría emitirse... Las normas que imponen la observancia de una forma especial son de interpretación estricta... Prescindiendo de lo que pudiera ser el uso espontáneo de la forma escrita por el declarante, con finalidad probatoria, hay casos en que el ordenamiento jurídico la impone... El negocio sujeto a forma escrita esencial se denomina solemne... La imposición de la solemnidad de forma se explica por el propósito de la ley de llamar la atencion del declarante sobre la importancia del acto que realiza y de garantizar la seriedad y madurez de todo lo que él decida hacer...; de hacer posible siempre el control del contenido de la declaración y de constreñir al declarante a la claridad. . .La forma solemne se exige. . .para los actos que se refieren al estado de la persona (considerada en sí y en su posición en la familia)... A veces, la forma escrita puede asumir una solemnidad más acentuada.... Es acto público o auténtico aquél que ha sido redactado con las formalidades del caso... por un notario o por otro funcionario público (oficial de estado civil... )".

"En cuanto a la forma, escribe León Barandiarán (2), todo acto debe revestir alguna formalidad, entendida ésta como la manifestación exteriorizada del consentimiento (la declaración de voluntad)....En caso de que la ley imponga una determinada forma (acto solemne), si el acto no reviste la misma, él no tiene validez..."

(1) Francesco Messineo. Derecho Civil y Comercial, t. II, p. 381. Buenos Aires, 1954

(2) José León Barandiarán. Manual del Acto Juridico, p. 14. Lima, 1950 
Ocupándose específicamente de la forma substancial del matrimonio, los autores del Diccionario de Derecho Privado, Casso y Cervera (3), se refieren a "un conjunto de actos que implican una forma externa, precisa y legalmente exigida para la prestación del consentimiento constitutivo de cada matrimonio", que "por la importancia social del matrimonio y su trascendencia familiar... la importancia y trascendencia de las obligaciones y deberes matrimoniales" ... exige que "los contrayentes se den perfecta cuenta de la trascendencia del acto que realizan..." el mejor medio para lograrlo es rodear la celebración del matrimonio de solemnidades especfficas y extraordinarias..." "Implica, pues, este elemento legal todo un aparato técnicojurídicopositivo, encaminado tanto a la solemnidad exigida por la trascendencia del matrimonio... como para preparar una fácil y hacedera prueba del mismo"...

Ocupándose del Código Civil de 1852, Toribio Pacheco (4) solamente utiliza la palabra "formalidades" al tratar de la celebración del matrimonio (que entonces era sólo uno: el canónico). "Respecto a la manera de celebrarlo - dice-- es preciso llenar las formalidades que la ley impone"... "El matrimonio como contrato civil está fundado, entre nosotros, en la institución como sacramento; de manera que, para producir efectos civiles, debe ser celebrado... con las formalidades establecidas por la Iglesia".

El significado que estos dos tratadistas, uno extranjero y el otro nacional, otorgan a la palabra formas del matrimonio es virtualmente universal.

Ruggiero (5) distingue, entre los requisitos para contraer matrimonio, los sustantivos - diferencia de sexo, pubertad, consentimiento libre... - los "requisitos de forma" y a ellos se refiere bajo el nombre de formalidades preliminares - publicación del proyecto, previa presentación de ciertos documentos... - y de formalidades referentes a la celebración misma del matrimonio - publicidad $y$ oralidad de la interrogación que hace el oficial de estado civil,

(3) Casso y Cervera. Diccionario de Derecho Privado, t. I, p. 1971. Barcelona, Madrid ... 1950

(4) Toribio Pacheco, Tratado de Derecho Civil, t. I, Lima, 1860, p. 184

(5) Roberto de Ruggiero. Instituciones de Derecho Civil, t. II, vol. $2^{\circ}$. Madrid. . pp. 75 a 96 
inequivocidad de la respuesta afirmativa de los pretendientes, suscripción del acta...

Jemolo (6) coincide enteramente con estas apreciaciones. Luego de ocuparse extensamente de la institución matrimonial (esponsales o promesa de matrimonio, capacidad para contraerlo, impedimentos, el problema del consentimiento... ), dedica una sección completa a "La celebración", distinguiendo en ella "las formalidades preliminares (sistema de publicación dispensa de ésta, penalidades...); la oposición; "la celebración" (sus momentos, intervención de apoderado, pronunciamiento del oficial del estado civil...) y las pruebas de la celebración.

Por su parte, Enneccerus, Kipp y Wolff (7), bajo el epígrafe genérico de "Conclusión del Matrimonio" y haciendo referencia a la ley del Reich de 6 de febrero de 1875, señalan la presencia de dos testigos, la interrogación del funcionario a los pretendientes, la respuesta afirmativa de éstos y el pronunciamiento del funcionario del estado civil de haber quedado aquéllos unidos en matrimonio; añade que "además de estas disposiciones formales esenciales, cuya infracción hacía nulo el matrimonio, existian ciertas 'disposiciones de orden (imperfectas)' sobre la competencia del funcionario, las proclamas, las condiciones de los testigos y la inscripción del matrimonio en el registro de casamientos"; y luego enseñan que el Código civil mantiene el matrimonio civil obligatorio. Más adelante, al ocuparse de los vicios de la conclusión (celebración) del matrimonio, estudian en primer término los "vicios de forma" y detallan sus consecuencias.

Lacruz Berdejo (8) es aún más explícito, cuando, luego de utilizar como epígrafe el de "Matrimonio canónico y matrimonio civil; matrimonio en forma religiosa y en forma civil", esclarece la cuestión que ahora nos ocupa expresando: "Distinto del binomio 'matrimonio religioso-matrimonio civil' es el circunscrito a la forma: 'matrimonio en forma religiosa' y en forma civil': Aquella dua-

(6) Arturo Carlo Jemolo. El Matrimonio. Buenos Aires, 1954,pp. 143 a 173

(7) Ludwig Enneccerus, Theodor Kipp y Martin Wolff. Tratado de Derecho Civil, $4^{\circ}$ tomo, vol. primero. Barcelona, 1953, pp. 111 y ss., 140 y ss.

(8) Jose Luis Lacruz Berdejo y Francisco de Asis Sancho Rebullida. Derecho de Familia. Barcelona, 1982, pp. 130, 131 
lidad tiene alcance institucional: se refiere a realidades jurídicas que, siendo matrimonios ambas, se estructuran en distinto ordenamiento tanto en lo referente a su constitución cuanto a sus efectos; se trata de dos clases de matrimonio. En cambio, la forma religiosa de celebración se limita a sustituir, con sus propios ritos, el régimen civil de emisión del consentimiento matrimonial y a permitir que lo reciba un ministro religioso en lugar del funcionario del Estado; pero en lo demás - requisitos de validez y régimen de la nulidad, impedimentos, dispensa, separación, disolución, etc.el régimen único es el civil..."

Esta opinión -sustentada precisamente por un jurista español, respetuoso de la Iglesia Católica o católico él mismo-tiene particular importancia para la cuestión materia del presente artículo, ya que, por una parte, diferencia con claridad las expresiones "formas de matrimonio" -que sólo se refiere al acto de celebración del casamiento-y "clases de matrimonio" - en que se trata de dos estatutos jurídicos diferentes. Según esto, es evidente que la fórmula contenida en el art. 5 de la Constitución Peruana - "formas" y no "clases" - no autoriza en modo alguno la coexistencia de dos o más regímenes matrimoniales diferentes, no sólo en su celebración, sino también en su contenido, efectos y eventual separación o disolución, sino únicamente la celebración del casamiento ante la autoridad civil o ante la o las religiosas (que es, exactamente, el alcance de la fórmula propuesta por el autor de esta nota en el seno de la Asamblea Constituyente y que el señor Huapaya desahucia).

Refiriéndose específicamente al Derecho Matrimonial Católico, Knecht (9) emplea la palabra forma sólo para referirse al acto de celebración del matrimonio; y distingue la forma ordinaria (en el Código de Derecho Canónico de 1917, recientemente sustituido), con intervención del párroco y asistencia de los testigos; y la forma extraordinaria de dicha celebración, en que el matrimonio se formaliza ante cualquier sacerdote y dos testigos o ante dos testigos solamente (Decreto Ne Temere).

Panorama semejante ofrece la doctrina jurídica latinoamericana en esta materia. Así:

(9) A. Knecht, Derecho Matrimonial Católico, Madrid, 1932, pp. 469 a 504 
Rébora (10) analiza extensamente los "Requisitos y celebración del matrimonio"; distingue entre los primeros los "personales" y los "formales"; y entre estos últimos, que son los que interesan a este estudio, menciona la presentación de los interesados ante el respectivo oficial público, la manifestación verbal de su intención, la presencia de dos testigos y la suscrición de una nota; todo lo cual antecede a la celebración misma del casamiento, que tiene lugar con la comparecencia personal -o eventualmente por apoderado- ante el oficial del Registro Civil; "a puertas abiertas"; y que consiste en la ratificación de propósitos, el intercambio de declaraciones luego de la lectura de ciertos artfculos pertinentes, el pronuriciamiento de la unión y la extensión de un acta. Estas son las formalidades o formas del matrimonio.

A su turno, Belluscio (11), después de examinar los "requisitos intrínsecos del matrimonio" (impedimentos), desarrolla in extenso el tema de los "Requisitos extrínsecos: forma y prueba del matrimonio"; y luego de señalar la "importancia de las formas" en los antecedentes históricos y en el Derecho comparado, estudia las diligencias previas, que consisten básicamente en la expresión verbal de la intención de contraer matrimonio ante el oficial público encargado del registro civil, con asistencia de dos testigos y suscripción de un acta; y en la ceremonia misma del casamiento ante el oficial encargado del Registro Civil, en su oficina, públicamente, compareciendo personalmente los futuros esposos o eventualmente sus apoderados, en presencia de dos testigos y con las demás formalidades que la ley prescribe...

Borda (12) dedica el cap ftulo II de su obra a la "Celebración del Matrimonio" y divide la materia en tres partes: I. Impedimentos. II. Consentimiento. III. Forma; y en esta última, después de señalar la importancia de las formas en el matrimonio, a las que también denomina formalidades o solemnidad, comenta la ley argentina según la cual, suprimida la publicación de los avisos, el

(10) Juan Carlos Rébora. Instituciones de la Familia, Buenos Aires 1946, T. II pp. 51 y ss. y 96 y ss.

(11) Augusto César Belluscio. Derecho de Familia, Buenos Aires, 1979. T. I. pp. 311 y 570 y ss.

(12) Guillermo A. Borda. Tratado de Derecho Civil Argentino, Familia, I. Buenos Aires, 1969, pp. 120 y ss. 
matrimonio se realiza en un solo acto, públicamente, en la oficina del Registro Civil, con lectura de determinados artículos del Código referentes a las obligaciones más importantes de los cónyuges, la expresión del consentimiento por cada uno de los contrayentes $y$ el pronunciamiento del funcionario en nombre de la ley en el sentido de quedar aquéllos unidos en matrimonio; de todo lo cual se deja constancia en acta. Precisa, en fin, las sanciones que se imponen según la ley por la inobservancia de las formas, según que de ellas dependa la existencia del acto o no.

Aludiendo a la legislación chilena sobre el particular, Somarriva (13) enumera, en primer lugar, los "requisitos de validez" y entre ellos menciona el consentimiento libre y espontáneo, la capacidad de los contrayentes (esto es, la ausencia de impedimentos dirimentes) y el cumplimiento de las formalidades exigidas por la ley. Luego analiza, bajo el nombre de "solemnidades" las formalidades que deben cumplirse en el acto de la celebración del casamiento (y que son semejantes a las exigidas en las otras legislaciones).

Coincidentemente, y aun con mayor claridad, Fueyo (14), explica que "así como requisito se refiere a los requisitos de fondo..., la expresión formalidad representa las formas, o formalidades o solemnidades ad sustantiam"; y desarrollando este esquema clasifica en seguida las formalidades (o formas) en anteriores al matrimonio, coetáneas a su celebración y posteriores a ésta. Incluye entre las primeras la manifestación de voluntad por los pretendientes y la información de dos testigos; enumera entre las segundas el día y hora de la celebración, el lugar en que ésta se hace, la ceremonia propiamente dicha y los testigos del acto. Incluye, en fin, entre las terceras el acta del matrimonio, la inscripción de éste y la expedición del certificado. Aquí terminan las formas del matrimonio.

Emilio Valverde, en fin (15) -para no alargar indefinidamente las citas de autoridad-, con referencia específica al Derecho pe-

(13) Manuel Somarriva Undurraga. Derecho de Familia, Santiago de Chile, 1946 , pp. 29 y ss. 59 y ss.

(14) Fernando Fueyo Laneri. De recho Civil, t. VI, vol. I. Santiago de Chile, 1959 , pp. 120 y ss.

(15) Emilio F. Valverde. El Derecho de Familia en el Código Civil Peruano, t. I. Lima, 1942, pp. 211 y ss. y 242 y ss. 
ruano, se ocupa de las formalidades al tratar de la celebración del matrimonio; formalidades de las que unas son previas - destinadas a fijar la capacidad de los contrayentes, y otras alusivas a la ceremonia misma.

Especial interés reviste en esta materia la lectura de las actas de la Comisión Reformadora del Código Civil de 1852. cuyos trabajos dieron origen al de 1936.

Como es sabido, dicha Comisión estuvo integrada por cuatro de los más notables juristas peruanos de la época, los señores Oliveira -quien fue precisamente el autor de la ponencia sobre el Libro de Familia-, Juan José Calle, M.A. Olaechea y A. Solf y Muro. La Comisión debatió a fondo, con acopio de argumentos y a veces en términos caballerosamente polémicos e incisivos, precisamente los temas relacionados con el mantenimiento del matrimonio católico como el único obligatorio para los católicos -que eran, como siguen siendo, la inmensa mayoría de los peruanos-y del matrimonio civil para los no católicos, establecido por ley de 23 de diciembre de 1897; o la implantación del matrimonio civil obligatorio; en todas las implicaciones que el tema conllevaba. De hecho, la Comisión debatió exhaustivamente la materia a lo largo de doce intensas sesiones efectuadas entre 31 de octubre de 1923 y 16 de enero de 1924 (sesiones 52 a 63), y volvió sobre la misma en otras ocasiones, como en las de 23 de setiembre de 1925 y 31 de marzo de 1926.

Pues bien, la expresión formas del matrimonio fue utilizada no menos de diecisiete veces con los alcances que el autor del presente artículo atribuye a la fórmula del art. 5 de la nueva Constitución y no con la que les atribuye la interpretación del señor Huapaya. Con ese significado la utilizaron, desde luego, el propio ponente, y también los demás juristas de la Comisión; y sólo en dos ocasiones empleó el señor Calle expresiones equívocas al respecto.

Una nota puesta oficialmente al pie de la pág. 128 del volumen en que se registra la extensa Memoria presentada por el ponente del Libro de Familia en la sesión de 31 de octubre de 1923, consigna, además, la opinión vertida por el señor Manuel Vicente Villarán en el Senado de la República, según la cual debía permitirse la celebración del matrimonio religioso y del civil... dándose a 
ambos matrimonios igualdad de efectos ante la ley", lo que refuerza la interpretación de que la dualidad de formas hacía referencia, no a dos clases de matrimonio, sino a uno sólo que podría celebrarse en dos formas.

En cambio, no nos ha sido posible encontrar opiniones autorizadas que entiendan "formas de matrimonio" como "clases" o "tipos" de matrimonios. Cuando, eventualmente, algunos de los tratadistas nombrados quiere referirse a matrimonios diferentes utiliza precisamente las recién recordadas expresiones: clases o tipos o regímenes o estatutos juridicos - no formas- matrimoniales.

En fin, resulta significativo que el mismo señor Huapaya y también el director de la tesis señor Fuenmayor empleen en ella repetidamente la expresión las formas en el sentido que defendemos, que es el correcto. Así, al referirse al sistema de matrimonio facultativo que existe en algunos Estados, precisa que en él "los novios tienen plena facultad para contraer matrimonio o en forma civil delante del ministro estatal, o en forma religiosa delante del ministro de culto competente" (p. 462); y poco más adelante, con especifica referencia al tipo anglosajón de matrimonio facultativo, insiste en que en él "sólo existe la libertad en cuanto a que los contrayentes pueden manifestar su consentimiento delante del ministro de culto o delante del funcionario civil. Se trata, pues, exclusivamente de una libertad para elegir entre dos formas de celebración; correspondiendo al Estado..." etc. En cambio y en evidente contraste, cuando el autor quiere aludir a dos sistemas jurídicos matrimoniales distintos utiliza, como es correcto, la palabra clases. Así, en la página inmediatamente siguiente, señala que "en la modalidad latina o católica el Estado... ofrece la posibilidad de optar entre dos clases de matrimonio: el civil y el canónico..." "El complejo conjunto de formalidades y la misma ceremonia civil constituyen un ropaje jurídico con el que tiene que revestirse el matrimonio para obtener efectos en el ámbito del fuero civil" (p. 469). Y poco más adelante, al comentar el matrimonio in extremis que el Código de 1936 autorizaba en su art. 120, dice que "el hecho (de) que el Código Civil no autoriza a un funcionario civil para proceder en forma tan sumaria, indica... etc." (p. 471, nota 29). Nuevamente, en la p. 502 utiliza la expresión forma de la celebración en el sentido correcto, es decir, vinculada a la ceremonia del casamiento (matrimonio como acto) y no como sinónimo 
de régimen matrimonial (que comprende al matrimonio tanto como acto cuanto como estado, desde su principio hasta su terminación). Idéntica significación tiene la palabra formas en la tesis del señor Huapaya cuando comenta que por el primer párrafo (del art. 316 del proyecto presentado a la Comisión Reformadora del Código Civil de 1936) "el matrimonio religioso al que se reconoce efecto civil es el contraído según los cánones del Derecho de la Iglesia y no sólo el celebrado en la forma establecida por el "ordenamiento civil" (p. 405). Y como síntesis del criterio que subyace en el empleo correcto de la palabra formas, recuerda (p. 496) que "tanto el Derecho Canónico como el Derecho Civil construyen la teoría de la validez del matrimonio sobre estos tres elementos: sujetos hábiles, consentimiento y forma...

Toda la confusión que, según parece, existe en la tesis en cuanto a los alcances de las expresiones formas y clases (o tipos o regímenes) podría, a nuestro juicio, desvanecerse si se recordara que la palabra matrimonio tiene en Derecho dos significaciones conexas pero claramente diferenciables: el matrimonio como acto y el matrimonio como estado. El primero se realiza a través de un trámite, que generalmente comienza con la declaración que hacen los interesados de su propósito de casarse, que suele seguir con la publicidad que se da a ese proyecto a fin de franquear la vía a eventuales oposiciones o denuncias de impedimentos, que suele continuar con una declaración formal del oficial respectivo en el sentido de haber quedado acreditada la capacidad nupcial, y que culmina en una ceremonia de realización del proyecto. A partir de ese momento, comienza el matrimonio como estado, el cual nace con una vocación de permanencia (vitalicia para los católicos y en todo caso duradera y no fugaz), se prolonga a través de un complejo de relaciones personales ("deberes y derechos que nacen del matrimonio", les llama nuestro Código: fidelidad, cohabitación, asistencia, dirección del hogar, su representación ante terceros... ) y patrimoniales (régimen de bienes y deudas... ), que a veces decae (a través de la separación de cuerpos) y que un día se disuelve (sea por la muerte o, en los países que lo admiten, por el divorcio).

Ahora bien, el ordenamiento legal coge el matrimonio desde la declaración del propósito de casarse que hacen un varón y una mujer ante el oficial autorizado hasta que la muerte (o el divorcio) pone fin a la relación; y el complejo orgánico de normas que dicho 
ordenamiento contiene se llama régimen matrimonial. Cada régimen regula, pues, una determinada clase de matrimonio. En este sentido, hay un régimen católico o canónico, uno judío, otro musulmán... y así más o menos indefinidamente. Un Estado cualquiera puede acoger una sola clase de matrimonio o puede acoger a varias. En este último caso, se dirá que el sistema matrimonial de tal Estado acoge varios regimenes matrimoniales (o varias clases o tipos de matrimonios).

Ahora bien, tratándose del matrimonio como acto, su validez exige, como cualquier otro acto o negocio jurídico, la concurrencia de tres elementos: sujetos hábiles (que son quienes no tienen impedimentos legales para casarse), objeto licito (que es la unión matrimonial) y forma prescrita por la ley (o formas, como ocurre en otros actos jurídicos que pueden ser realizados en varias formas, como el reconocimiento de hijos extramatrimoniales o el otorgamiento de testamento...)

La palabra forma o formas (o formalidades) tiene, pues, un alcance mucho más restringido que la palabra clases (o regímenes o tipos), pues sólo se refiere a uno de los elementos del matrimonio como acto, mientras que el régimen matrimonial (y puede haber varios) regula todo el fenómeno matrimonial, desde que se proyecta hasta que se disuelve.

A la luz de este enfoque, resulta claro que la expresión formas de matrimonio que utilizó el legislador constituyente en el art. 5 no puede entenderse como sinónimo de clases de matrimonio, sino solamente como la admisión de varias formas de celebrarse el matrimonio (ante el funcionario del Estado, ante un párroco, o ante un rabino o ante un pastor... por ejemplo); pero que, una vez celebrado el matrimonio en una de esas varias formas, queda sujeto (y aquí se igualan todos los matrimonios) a un solo régimen jurídico, que es el del Estado Peruano, el cual además de precisar cuáles son esas diferentes formas de celebración, regula todo su contenido (condiciones necesarias para casarse válida y lícitamente -impedimentos dirimentes e impedientes y, por tanto, causales de nulidad, anulabilidad e ilicitud del matrimonio-- relaciones personales entre los cónyuges, régimen patrimonial o regímenes patrimoniales, causales de decaimiento del vínculo y, en fin procedencia y en su caso causales de divorcio... ). 
Si se tiene a la vista este enfoque, resulta desconcertante que el autor de la tesis, no sólo confunda formas con tipos o clases, sino que llegue a atribuir a las primeras mayor extensión que a las segundas, cuando es exactamente al revés. Así, sostiene que "los debates posteriores (de la Comisión Principal de la Asamblea Constituyente) determinaron que la fórmula amplia contenida en la expresión formas de matrimonio prevaleciera sobre aquélla que defendía un sistema dualista de reconocimiento de dos tipos de matrimonio" (p. 479); todo ello sin contar con que la fórmula que reconocía efectos legales al matrimenio religioso en ciertos casos nunca propuso varios tipos de matrimonio, sino varias formas de celebrarlo.

Vale la pena señalar, en fin, aunque sólo sea en términos muy abreviados, que si se considera el problema desde el punto de vista, ya no de la doctrina jurídica, sino del Derecho positivo peruano, se podrá advertir que ni en el Código Civil de 1852, ni el de 1936, ni en el actual de 1984 utiliza el legislador la palabra formas cuando quiere aludir a clases o regímenes (Puede verse al respecto, como simple ejemplo, el texto de los arts. 295 a 302, 307, 318 a $320,326,327,329$ a 331 , etc.); y, sobre todo, que la fórmula del art. 5 de la nueva Constitución tuvo originalmente una formulación más extensa, cuyo conocimiento esclarece aún más el asunto. "La ley regula las formas de matrimonio y las causas de separación y disolución así como sus efectos".

Pues bien, si la expresión formas hubiera sido utilizada como sinónima de regímenes o clases de matrimonio, habría sido ociosa y repetitiva la indicación de que también la ley habría de regular los efectos del matrimonio y las causales de decaimiento y disolución, pues el régimen abarca todo eso: celebración, contenido, decaimiento y disolución. Resulta, pues, evidente, tambien desde este punto de vista, que la palabra formas sólo cubría una parte del régimen, atinente a la ceremonia del casamiento, en tanto que el resto -efectos, decaimientos y terminación-también serían reguladas por la ley, además de regular las formas o formalidades de su celebración.

\section{de 1979 \\ 2. Iter legislativo del párrafo $2^{\circ}$ del art. 5 de la Constitución}


El segundo camino por el cual es posible, a nuestro juicio, esclarecer los alcances de la equívoca expresión usada por el constituyente es el histórico: consiste en seguir la pista o itinerario de la iniciativa, desde sus orígenes hasta la aprobación del texto final, en el seno de la propia Asamblea Constituyente.

Los documentos básicos para ello son los tomos I y II, referentes al trabajo de la Comisión Principal --encargada de elaborar el proyecto de la nueva Carta, sobre la base de los anteproyectos o ponencias de las comisiones especiales-y el tomo VI de los Debates del Plenario de la propia Asamblea Constituyente que debatió, aprobó y promulgó la Carta de 1979.

El autor de la tesis ha tenido, en efecto, a la vista esos volúmenes; pero, sea por insuficiente prolijidad o porque él mismo no participó obviamente en los trabajos de la Constituyente, ha perdido varios pasos de ese itinerario; y no ha logrado captar ni interpretar, entre otras circunstancias, una curiosamente significativa: la de que el seguimiento del iter legislativo, en este caso concreto, resulta más ilustrativo por sus silencios y omisiones, que por sus expresiones directas.

El itinerario en cuestión se puede sintetizar así:

1. El 27 de octubre de 1978 llega a la Comisión Principal, proveniente de la Comisión Especial $\mathrm{N}^{\circ} 3$-encargada del anteproyecto sobre esta materia - un art. $4^{\circ}$, cuyo párrafo tercero reza: "La ley regula las formas de matrimonio y las causas de separación y disolución, así como sus efectos" (Tomo II, p. 31, Anexos y Ponencias de la Comisión Principal), sin que en la brevísima exposición contenida en el oficio de remisión se diga una sola palabra acerca del fundamento y los alcances de aquella iniciativa.

2. El 19 de diciembre del mismo año, el señor Aramburú propone que se suprima en dicho texto la expresión: "La forma de..." (así, en singular) (T.I, p. 65);

3. En esa misma fecha y sesión se deja constancia de que el mencionado párrafo fue "retirado por la Comisión". (Conviene señalar que el artículo en cuestión, que llevaba originalmente el número 4 , pasó después a tener el número 5 , de lo que se deja constancia para evitar confusiones) (T.I, p. 66). 
4. En la sesión de 28 de diciembre, el señor Cornejo Chávez pide que se ponga a discusión la adición presentada por él sobre el matrimonio religioso; pero no se llega a debatir (T. I, p. 82);

5. En sesión de 2 de enero de 1979 , el señor Cornejo Chávez recuerda a la Comisión que hay dos adiciones pendientes de discusión: una sobre el matrimonio religioso y la otra sobre el servinakuy (T.I, p. 85); y en la misma oportunidad se aprueba sin discusión ni objeción de nadie la adición propuesta por el señor Cornejo Chávez, cuyo texto es el siguiente: "Se reconoce efectos civiles al matrimonio religioso inscrito en el Registro del Estado Civil". Luego, en la misma sesión, el señor Ramirez del Villar pide se reconsidere la decisión adoptada sobre el párrafo $3^{\circ}$ del art. $5^{\circ}$ (retirado antes, como se ha dicho, por la Comisión), y, en efecto, se aprueba ese párrafo.

6. Con fecha $30 \mathrm{del}$ mismo mes de enero, la Comisión acuerda el ordenamiento de los incisos del art. 5, "incluyendo las adiciones de los señores Ramírez del Villar y Cornejo Chávez relacionadas con la regulación de la forma (sic: en singular) del matrimonio y los efectos civiles del matrimonio religioso inscrito en los registros de estado civil" (T.I, p. 165);

7. El 8 de febrero fueron aprobados los siete cap itulos del Título de Derechos y Deberes Fundamentales de la Persona (cuyo capítulo II se refiere a la familia) (T.I, p. 189);

8. En sesión de 8 de marzo se acuerda que la adición del señor Cornejo Chávez sobre reconocimiento de efectos civiles al matrimonio religioso, aprobado el 2 de enero, quede signado con el No 4-A del capítulo II: Familia) (T.I, p. 265);

9. El 13 de marzo, el art. 4-A fue ratificado con ese número (T.I, p. 273);

10. Con fecha 27 del mismo mes de marzo de 1979 , se remite al Presidente de la Asamblea Constituyente el proyecto final de la Comisión Principal sobre Derechos de la Familia, cuyo art. $4^{\circ}$, párrafo $3^{\circ}$ dice que "el matrimonio religioso inscrito en el Registro de Estado Civil produce efectos legales" (T.II, p. 282);

11. En sesión de 9 de abril de 1979, el Presidente de la Comi- 
sión Principal consulta a ésta acerca de los pedidos de reserva respecto del capítulo II (De la Familia). "Efectuado el procedimiento con relación a varios artículos del indicado capítulo, no se acordó reserva alguna" (T.I, p. 332);

12. El mismo día, por la noche, en el Plenario de la Asamblea Constituyente, el Presidente anuncia que al día siguiente, por la mañana, habria sesión de la Comisión Principal... para considerar las modificaciones sobre el capitulo II que surjan del debate de hoy"; y que habría sesión plenaria de la Asamblea el día subsiguiente por la mañana (T. VI, p. 4);

Se da entonces lectura al texto del capítulo II, cuyo art. $4^{\circ}$, párrafo final preceptúa que "el matrimonio religioso, inscrito en el Registro de Estado Civil, produce efectos legales" (T.VI, p. 10).

En ese momento, el señor Biaggi anuncia llanamente, sin expresar fundamento alguno ni dar ninguna explicación, que, por acuerdo de los dos partidos que formaban mayoría, propone que se suprima el indicado párrafo tercero (Además se refiere a otros puntos ajenos a esta materia). El señor Ramírez del Villar, sin referirse al anuncio del señor Biaggi, propone, en nombre de su grupo, otras enmiendas a otros art ículos del capítulo II (T. VI, pp. 12-13)

Ante esta sorpresiva decision adoptada fuera de sesión por los dos grupos de mayoría, el señor Cornejo Chávez manifiesta su sorpresa, pues ello significa dejar de lado la intención que se tuvo al constituir la Comisión Principal multipartidaria, integrada por los diez grupos políticos representados en la Constituyente y en cuyo seno debía buscarse las fórmulas de consenso (p. 17), señala que son esenciales las modificaciones acordadas extra-sesión por dichos dos partidos (p. 18), y hace notar que el asunto ha quedado virtualmente terminado, por lo que carecía de objeto entrar en mayores reflexiones (p. 19). Sigue, luego, un intercambio de ideas con intervención de otros dos señores constituyentes, cuando el asunto estaba ya clausurado y el debate carecía de objeto

13. Vuelto el asunto a la Comisión Principal, en sesión de 10 de abril de 1979, el Presidente da la razon al señor Cornejo Chávez en cuanto al procedimiento adoptado por los dos partidos de mayoría; y luego pone en debate el párrafo $3^{\circ}$ del art. $4^{\circ}$ sobre el matrimonio religioso "que estaba pendiente" (T.I, p. 333, Com. Principal). 
El señor Cáceres Velásquez propone que se diga "matrimonio canónico"; y el señor Ramírez del Villar del Partido Popular Cristiano "se opuso a la idea de reconocer efecto civil al matrimonio religioso, así como al canónico", posición a la que se sumó el señor Del Prado del Partido Comunista.

No obstante haberse aprobado un pedido del señor Cáceres en el sentido de que se reservara el párr. $3^{\circ}$ "en vista de no estar presente el señor Cornejo Chávez", se procede a aprobar la fórmula venida de la Comisión Especial $N^{\circ} 3$ acerca de que "las formas de matrimonio y las causas de separación y disolución son reguladas por la ley" (pp. 334-336) y en relación a la propuesta del señor Cornejo Chávez se expresa que "después de un amplio y detenido análisis de las fórmulas y modificaciones presentadas, en la que los señores miembros de la Comisión hicieron conocer sus respectivos puntos de vista, se procedió a votar. Leída y puesta al voto la formula original, fue rechazada". "Igualmente, no fue aprobada la nueva proposición sobre matrimonio canónico. En consulta la piupuesta bipartidaria (sic) que reconoce efectos legales al matrimonio religioso o canónico, fue desestimada....". "Consultada la redacción sustitutoria propuesta por el señor Ramírez del Villar, fue aprobada". Sale así la fórmula definitiva del párrafo $3^{\circ}$ : "las formas de matrimonio y las causas de separacion y disolución son reguladas por la ley" (p. 336).

14. Vuelto el asunto al Plenario de la Constituyente en sesión de 11 de abril, a las $11.30 \mathrm{a} . \mathrm{m}$. el Presidente anuncia que está cerrado el debate con respecto al capítulo II y, "de conformidad con lo acordado", "la Comisión Principal... ha considerado las observaciones hechas al texto del indicado capitulo, que está en poder de los señores miembros de la Asamblea y sobre lo cual se va a votar" (T.VI, p. 39). El señor Cáceres pide que el artículo $4^{\circ}$ se vote separadamente. La presidencia, una vez oida la opinión del señor Polar, rechaza ese pedido. Así se vota en bloque todo el capítulo II. "Sin debate y por unanimidad - dice el acta de esa sesión-fue aprobado el capítulo II". Pero dejan expresa constancia de sus desacuerdos y reservas representantes que pertenecen a seis de los diez grupos políticos representados en la Asamblea.

Este es, a nivel de la Asamblea Constituyente, el iter legislativo del artículo $5^{\circ}$ de la nueva Constitución. 
Su lectura sugiere, desde luego, varias reflexiones, a saber:

a) La paternidad de la iniciativa aprobada nunca quedó ave-. riguada. Desde luego, no correspondió al señor Ramírez del Villar, quien se limitó a promover alguna vez su dẹbate y la defendió, porque la fórmula llegó a la .Comisión Principal de la Comisión Especial $N^{\circ} 3$, de la cual sólo formaron parte los señores Polar, Heysen, Roca, Ramos Alva y Valle Riestra (que suscribieron sin reservas el anteproyecto elaborado por dicha Comisión), la señora Magda Benavides (que no suscribió ese documento y anunció que después haría conocer sus discrepancias) y el señor Pedro Cáceres Velásquez (quien firmó el anteproyecto, pero anunció también observaciones y discrepancias).

El hecho de no saberse a quién o a quiénes correspondió la iniciativa no tiene sólo un interés anecdótico, sino uno muy importante: el de no poderse averiguar cuáles fueron los fundamentos y sobre todo los alcances de la expresión "las formas de matrimonio..." que utilizó, siendo así que ése fue el momento en que el problema se originó.

Formalmente, tal explicación pudo esperarse de quienes firmaron el anteproyecto o ponencia de la Comisión Especial $\mathrm{N}^{\circ} 3$; pero de ellos sólo los señores Polar y Valle Riestra integraron la Comisión Principal y nada dijeron al respecto, ni lo aclararon tampoco los demás en el Plenario de la Constituyente.

2. Otras dos ocasiones hubo para que el autor o los autores de la fórmula explicaran sus alcances: aquélla en que la Comisión retiró el párrafo respectivo (19 de diciembre de 1978) y aquélla en que el señor Ramírez del Villar obtuvo que se volviera a incluir (aparte de que tampoco queda clara la razón de readmitirse el 2 de enero de 1979 lo que se había retirado catorce días antes).

3. Tampoco aparece explicada la razón de que, dejảndose en pie la aprobación de la fórmula del señor Cornejo Chávez, se aprobara luego la del señor Ramírez del Villar, que parecían ser alternativas excluyentes y no fórmulas complementarias la una de la otra.

4. La petición - si bien no aceptada-que formulara el señor 
Aramburú en el sentido de que se suprimiera la fórmula en cuestión revela que ni aun dentro del mismo grupo político del señor Ramírez del Villar se tenía clara la idea de los alcances de la fórmula, pues aquél se refiere a la frase en singular ("La forma de matrimonio... "), lo que altera radicalmente la figura.

5. Desde el 2 de enero de 1979 hasta el 9 de abril del mismo año, la Comisión Principal se pronuncia a favor de la fórmula del señor Cornejo Chávez hasta en siete oportunidades; y así llega al Plenario de la Constituyente.

6. Una nueva oportunidad en que se pudo explicar los alcances de la expresión equívoca o ambigua finalmente aprobada ("las formas de matrimonio... son reguladas por la ley") fue aquella -9 de abril de 1979 en que el señor Biaggi, en nombre de su partido, el Apra, y del Partido Popular Cristiano, pidió -virtualmente anunció la decisión, porque esos grupos formaban mayoría- el retiro de la fórmula del señor Cornejo Chávez, con lo cual sólo quedaba precisamente la fórmula ambigua $\mathrm{y}$ equívoca finalmente aprobada. La ocasión fue nuevamente desaprovechada, pues el señor Biaggi no explicó y ni siquiera aludió a los alcances de la fórmula que quedaria.

7. Al interior de la Comisión Principal, al día siguiente, una cosã pareció esclarecida, a saber, que en opinión del Partido Popular Cristiano "las formas..." aludidas no podrian ser en ningún caso ni la canónica ni de ninguna otra religión, pues en ese sentido se pronunció el señor Ramirez del Villar, miembro de uno de los partidos de mayoria, a quien respaldó el señor Del Prado, del Partido Comunista.

8. La última oportunidad que se tuvo en la Constituyente para precisar el significado y alcances de la tantas veces mencionada expresión se perdió en la noche del 9 de abril de 1979, cuando se puso al voto, sin debate alguno porque la Presidencia anunció que ya estaba cerrado, la fórmula en referencia. No habiendo, en efecto, posibilidad de debatir el tema, los representantes que, por un motivo $u$ otro, estaban en desacuerdo con el Capitulo II sobre la familia, tuvieron que limitarse a anunciar sus discrepancias y reservas sin poder explicarlas ni precisarlas. Como se ha dicho, esos representantes pertenecían a seis de los diez grupos políticos inte- 
grantes de la Constituyente. Frente a sus declaraciones, resulta en verdad rectificada la afirmación oficial de que el Capítulo había sido aprobado por unanimidad.

El iter legislativo del párrafo segundo del art. 5 de la Constititución revela, pues, que en ningún momento se dijo ni se dio a entender que con ese párrafo se buscase.y se fuese a operar en el Perú una cuasi-revolución en materia de matrimonio, porque esto, y nada menos, significaria admitir la tesis de que con la mencionada fórmula quedaba abierta en el Perú la posibilidad de admitir varios regímenes o clases de matrimonio, algunos de ellos fuera de la legislación y jurisdicción del Estado, como piensa el señor Huapaya.

"Cuasi-revolución" decimos, y no exageramos pues de ser exacta la interpretación que impugnamos, no sólo se habría puesto fin al sistema de matrimonio civil obligatorio vigente desde 1930 . sino que, tratándose del matrimonio canónico, se habría ido más atrás -cronológicamente-que el Código de 1852. Este, en efecto, si bien remitió las solemnidades de celebración del matrimonio a lo establecido por la Iglesia en el Concilio de Trento y a la competencia de los tribunales eclesiásticos el conocimiento de las causas referentes a la nulidad del matrimonio y el divorcio (entendido sólo como separación de cuerpos), no sólo retuvo para el Estado el conocimiento de las demás causas -sobre esponsales, alimentos para los hijos, litis expensas, liquidación y devolución de bienes, las criminales sobre adulterio y en general sobre los efectos civiles del matrimonio-, sino que legisló extensamente sobre el propio matrimonio, en la Sección Tercera, a lo largo de diez títulos y casi cien artículos concernientes a esponsales, reglas generales sobre el matrimonio, personas incapaces de contraerlo, causas que impiden su celebración, consentimiento para el matrimonio de menores, deberes y derechos que nacen del matrimonio, divorcio ( $\mathrm{cn}$ la acepción limitada de simple separación de cuerpos), reglas a observarse en los juicios de nulidad de matrimonio y divorcio, y efectos de este último. Creó, además, los registros de estado civil.

Pues bien, si, después de varios siglos de vigencia del matrimonio canónico expresamente asumido por la ley civil, la sola dación de la ley de 23 de diciembre de 1897 , que permitio el matrimonio civil a los no católicos, originó prolongada controversia; si el pro- 
yecto de ley presentado en 1918 por el senador Angel Gustavo Cornejo, cuyo objeto se reducía a que las causas de nulidad de matrimonio fueran conocidas por los jueces civiles, suscitó un vivo enfrentamiento de pareceres; si la ley de matrimonio civil obligatorio y divorcio aprobada en las Cámaras en 1920 determinó tal reacción que el Ejecutivo hubo de vetarla; si en el seno de la Comisión Reformadora del Código Civil de 1852, que habría de dar nacimiento al nuevo de 1936, el acuerdo de todos los juristas integrantes en el sentido de mantener la indisolubilidad del matrimonio, no pudo impedir que se efectuase una prolongada y por momentos incisiva polémica; si el ambiente nacional se conmovió nuevamente cuando, en 1930, el Gobierno levantó el veto a la ley de 1920; y cuando, en fin, la ley 8305 obligó a los miembros de la Comisión Reformadora antedicha a incluir en el nuevo texto el matrimonio civil obligatorio y el divorcio vincular, el país volvió a asistir, y aun a participar, en un largo debate, ¿como suponer que, poco menos que subrepticiamente, sin dar explicación ni fundamento alguno, a través del empleo de una expresión equívoca usando el simplísimo arbitrio de aumentar dos letras y suprimir una tercera, se hubiese podido modificar radicalmente todo el sistema matrimonial vigente por décadas, al punto de abrir el camino hacia una pluralidad indefinida de clases de matrimonios, regida cada una o varias de ellas por un estatuto jurídico distinto y ajeno al Estado? $\mathrm{Si}$, en vez de escribir "las formas de matrimonio", se hubiera escrito "la forma del matrimonio", nadie habría podido interpretar esta última expresión sino como referida al conjunto de solemnidades o formalidades de su celebración. Añadir dos veces la letra "s" y suprimir una vez la letra "l", ¿habria de tener la virtualidad de producir semejante cambio sustancial?.

En definitiva y a nuestro entender. la reseña del itinerario seguido por el párrafo $2^{\circ}$ del art. 5 de la nueva Constitución no conduce a la conclusión que patrocina la tesis del señor Huapaya, sino a la que también conduce la hermenéutica jurídica: la expresión las formas...., usada en ese párrafo, se refiere solamente a las formalidades del acto de celebración del casamiento.

Terminando el iter legislativo del texto constitucional aludido tantas veces, comenzó otro proceso interesante a nivel de la Comisión encargada de estudiar la reforma del Código de 1936. En esa Comisión que inició sus labores en marzo de 1965, el autor de 
la presente nota fue encargado de preparar la ponencia correspondiente al Libro de Familia; y en ese carácter, interpretando la norma constitucional en el mismo sentido que ahora sostenemos y en virtud, no sólo de su declarada profesión de fe católica, sino de consideraciones jurídicas, históricas y sociológicas, propuso la fórmula - que más adelante se analizará con algún detalle - siguiente: "El matrimonio religioso, celebrado con sujeción a los cánones de la Iglesia Católica, produce efectos civiles siempre que se inscriba en el Registro del Estado Civil".

De momento, sólo desea el autor de este artículo referirse a un hecho que, a la postre, resultó decisivo: el Episcopado Peruano se dirigió por escrito, primero a la Asamblea Constituyente, y después, hasta en tres oportunidades - dos de ellas a través del Ministro de Justicia-, a la Comisión Reformadora del Código Civil de 1936, objetando esa fórmula y pidiendo su retiro.

El autor de este comentario no conoció la existencia del primero ni menos su texto; pero sí, aunque muy tardíamente - esto es, cuando su intervención en la Comisión Reformadora y aun, eventualmente, al nivel de la Revisora, había concluido- el de los otros tres.

Lo que importa destacar en este punto del comentario es que, en ninguno de esos tres documentos oficiales, la Iglesia interpreta el art. 5 de la Constitución como lo hace el señor Huapaya. Más allá de razones "de orden práctico" principalmente, la Iglesia Peruana pudo entonces invocar, en respaldo de su pedido, el argumento de que la fórmula propuesta por el ponente del Libro de Familia recortaba los alcances de la norma constitucional; y exigir, por tanto, que el nuevo Código expeditara el camino hacia el restablecimiento del matrimonio canónico como clase o especie de matrimonio diferente del civil (salvo, obviamente, que la Iglesia esté en desacuerdo con la interpretación del señor Huapaya o con el apoyo que este explicita en favor de un sistema de pluralidad de regímenes matrimoniales).

La Iglesia no insinuó siquiera ese argumento.

El tipo de argumentación empleado por el Episcopado vendría así a añadir una razón más en contra de la interpretación que 
se hace en la tesis que comentamos sobre el párrafo $2^{\circ}$ del art. 5 de la Carta Fundamental.

Algo más se puede aún agregar en el campo del análisis histórico: la fórmula propuesta por el autor de este comentario a la Comisión Reformadora del Código Civil de 1936 fue, primero, aprobada sin modificaciones por ésta, y luego, hasta antes de la intervención del Episcopado, por la Comisión Revisora.

La Comisión Reformadora estuvo integrada, sin duda, por los más ilustrados juristas del país. Ninguno de ellos podría ser calificado como desconocedor de la Constitución, y menos aún en asuntos cuyo desarrollo o implementación corresponde al campo del Derecho Privado. Pues ninguno de ellos objetó la fórmula del ponente.

Más significativamente todavía: la Comisión Revisora, que originalmente aprobó la misma fórmula sin modificación alguna, no sólo estuvo integrada también por juristas notables, sino que entre sus miembros figuraron precisamente los otros dos constituyentes que tuvieron intervención en la génesis y aprobación del párrafo $2^{\circ}$ del art. 5 de la Carta: los señores Ramírez del Villar y Cáceres Velásquez. Es obvio que, de haber resultado la fórmula del ponente diminuta con respecto a la norma constitucional o contraria a ella, la habrían objetado. Y no lo hicieron.

En una palabra final: hasta antes de la tesis que comentamos, nadie había dado al art. 5 constitucional, que sepamos, la interpretación que le da el autor de la tesis, esto es, que la expresión las formas de matrimonio equivale a clases, tipos, especies o estatutos jurídicos matrimoniales diferentes, de los cuales sólo uno debiera estar sujeto por entero a la legislación y jurisdicción del Estado Peruano (que cuando más, sólo podría extenderse a matrimonios contraídos por adeptos a confesiones carentes de ordenamiento jurídico propio).

\section{La vía de la interpretación por el absurdo}

Por este tercer camino se puede, en efecto, llegar a la misma conclusión a que creemos haber llegado por las vías de la interpretación jurídica y del recorrido histórico de la norma en cuestión. 
Desde luego, algunos de los argumentos antes reseñados ponen de manifiesto que la tesis que comentamos originaría ciertas situaciones lindantes con el absurdo. Pero hay otra circunstancia que, de ser exacta esa tesis, tendría que calificarse ciertamente como tal.

Sostiénese, en efecto, que, según el apartado $2^{\circ}$ del art. 5 de la Carta, no sólo podria existir, junto al ordenamiento civil del matrimonio, otro regulado por el Derecho Canónico, sino tantos otrós más como confesiones religiosas - con un ordenamiento juridico propio- existan en el Perú. Si, entre esas otras confesiones. se tratara de la judía o la musulmana, ya el propio autor de la tesis se ve en el caso de apuntar algunas limitaciones (ciertamente discutibles, a menos que se reconozca al Estado el mismo derecho de ponerlas a la confesión católica); mas si se recuerda que, junto a esas confesiones, sin duda respetables y serias, existen - y contemporáneamente proliferan-muchas otras que no parecen merecedoras de igual tratamiento, la interpretación que el autor de la tesis da al principio constitucional de la igualdad religiosa, llevaria al Estado a admitir y reconocer efectos civiles (y aun, eventualmente, a respetar todo un ordenamiento jurídico del matrimonio si tales confesiones ya lo tienen o lo crean o inventan) a formas de unión no sólo exóticas sino aun moralmente inaceptables.

Ciertamente, el autor de la tesis podría afïmar $-y$ lo insinúa claramente al tratar de las confesiones judía e islámica- que el Estado podría poner limitaciones o no aceptar ciertas normas en base al argumento del orden público; pero preciso será admitir que con el mismo criterio con que el Estado podría negarse a reconocer el repudio o la poligamia, podría también desconocer el principio de indisolubilidad del Derecho católico; $y$, en todo caso, la aplicación por el Estado, según su propio y soberano arbitrio, de restricciones fundadas en lo que él considera de orden público, introducirfa un elemento de discriminación y hasta de subjetividad inaceptables.

De otro lado, aun si fuese exacta ia afirmación del autor de la tesis, en el sentido de que, de todas las confesiones cristianas, sólo la católica tiene un ordenamiento jurídico propio, en tanto que las demás sólo tienen un conjunto de ritos, siempre quedará abierta la posibilidad de que esas confesiones se den a si mismas un Dé- 
recho matrimonial o de que sostengan que ya lo tienen. ¿Será el Estado quien decida qué confesiones religiosas tienen un ordenamiento juridico y cuáles no?

Recuérdese, además, que entre las confesiones cristianas, las hay que son admitidas en el propio mundo cristiano como confesiones dignas de tal nombre y otras que son más bien rechazadas o desdeñadas (16).

Súmese todavia a ello la proliferación contemporánea de organizaciones de indole religiosa, que se autodenominan confesiones religiosas, cada una de las cuales se cree a sí misma la verdadera; y entre ellas, algunas cuyas actividades comienzan a preocupar a las autoridades policiales, que practican métodos de proselitismo que entrañan verdaderos secuestros, que sacralizan el desenfreno sexual o que han originado ya sucesos, otrora increibles, de suicidio colectivo.

¿Debería el Estado reconocer a esas confesiones el derecho a organizar su propio ordenamiento jurídico matrimonial y respetarlo él mismo? ¿O podrá discriminar, a su juicio, a quiénes reconoce y a cuáles no? $Y$, de otro lado, ¿a partir de qué condiciones un grupo de personas puede pretender que se le reconozca como una confesión religiosa? ¿Qué organismo nacional o internacional será reconocido como competente para resolverlo? ¿Y qué criterios o elementos de juicio habría un tal organismo de tener en cuenta para decidirlo: el número de afiliados, la existencia de una jerarquía, un conjunto de ceremonias, ritos o solemnidades, un cuerpo de dogma, un ordenamiento juridico...?

Fácilmente se echa de ver la confusión, y aun la anarquía, que semejante criterio podría suscitar. Y nada hay, en nuestro concepto, ni en los debates de la Constituyente, ni en los textos de la teoría jurídica, ni en las normas habituales de la lógica que permita sostener que la expresión formas de matrimonio pueda tener se-

(16) En el número de enero-febrero de 1986, una publicación muy solvente -. "Mision sin Fronteras" de los PP. Combonianos- reproduce un cuadro según el cual la cristiandad se ha fragmentado en siete grandes bloques, con 156 tradiciones eclesiásticas y 20,800 denominaciones distintas y separadas. 
mejante significación, ni que la tengan las proclamaciones constitucionales sobre libertad e igualdad religiosa, privacidad de las creencias religiosas, o a -confesionalidad del Estado.

Un último comentario se podría añadir - que, de algún modo, tiene que ver con los tres caminos de interpretación reseñados-; y es que, conforme al texto literal del párrafo $2^{\circ} \mathrm{del}$ art. 5 "las formas de matrimonio serán reguladas por la ley" (obviamente la ley peruana). Por tanto, aun suponiendo, sin admitirlo, que la palabra formas sea sinónima de clases, el Estado Peruano no podría ceder a otra ley la regulación de esas otras clases, sino que tendría que regularlas él mismo; y entonces no se trataría de varias clases de matrimonio (civil, católico o de otra confesión), sino de varias clases de matrimonio civil.

\section{La fórmula alternativa presentada a la Asamblea Constituyente}

Aunque el autor de la tesis sólo alude de paso a la fórmula del epígrafe, presentada por quien suscribe este comentario, no es ocioso referirse a ella, porque a la vista de su texto y teniendo presente cuanto se lleva dicho acerca de la fórmula aprobada, no se acierta a comprender, o al menos a justificar, que el señor Huapaya no la comparta.

Dicha fórmula, como se ha dicho, fue la siguiente: "El matrimonio religioso, inscrito en el Registro de Estado Civil, produce efectos legales".

El texto no se refiere sólo al matrimonio canónico, sino a todo matrimonio religioso, por lo que todas las críticas adversas del señor Huapaya contra la fórmula más tarde presentada a nivel de La Comisión Reformadora del Código Civil -sobre pretendida violación de los principios constitucionales de libertad e igualdad religiosas, etc. resultan impertinentes respecto de la fórmula trascrita líneas arriba.

Aparentemente, las objeciones del autor de la tesis podrían ser:

a) La de que dicha fórmula era menos amplia que la finalmente aprobada; 
b) La de que, para que surtiera efectos legales el matrimonio religioso, debía inscribirse en el Registro de Estado Civil; y

c) La de las consideraciones principalmente de orden práctico por las cuales el Episcopado se opuso a esa fórmula (en oficio de cuya existencia no se dio cuenta en la Constituyente y cuyo texto sigue siendo desconocido para el autor de este comentario) presumiblemente las mismas que después expresó ante la Comisión Reformadora del Código Civil.

En cuanto a lo primero, no es exacto que la fórmula de quien suscribe esta nota fuera menos amplia que la finalmente aprobada, pues es evidente que, además de la forma civil de celebrarse el matrimonio y de las formas de las diferentes confesiones religiosas, no se concibe ninguna otra.

Tocante a lo segundo, cabe recordar que el Código Civil de 1852 , siempre defendido en esta materia por la Iglesia y entendemos que también por el señor Huapaya, también exigía la inscripción del matrimonio religioso en el Registro de Estado Civil para que se pudiera reclamar sus efectos (arts. 441 y 443 ) y que el art. 120 del Código Civil de 1936 preceptuaba que el matrimonio de. urgencia - celebrado, según la interpretación tanto del señor Huapaya como del autor de esta nota, según las formalidades canónicas- no producía efectos civiles si se contraía entre personas civilmente incapaces y mientras no se inscribiera en el Registro Civil (art. 126), sin que durante casi medio siglo de vigencia de dicho cuerpo de leyes se objetara esa exigencia.

Con relación, en fin, a la tercera, cabe señalar que las razones de orden práctico invocadas no hacen relación con la doctrina religiosa ni con la teoría jurídica; y, en todo caso, el peligro de confusiones en los feligreses tendrian que afrontarse, no necesariamente cambiando las leyes, sino ejecutando una política eficaz de adoctrinamiento y aleccionamiento a cargo de la misma Iglesia.

Es pertinente, sí, precisar que las razones por las que se presentó esa fórmula en la Asamblea Constituyente fueron $-y$ siguen siéndolo, a nuestro juicio- muy claras, a saber: primero, la ya comentada equivocidad de la expresión las formas usada por la Comisión Especial $\mathrm{N}^{\circ} 3$, segundo; porque esa fórmula constitucionaliza- 
ba el divorcio; y tercero, porque dicha formula habia sido retirada por la Comisión (aunque más tarde fue nuevamente incluida, suceso futuro que en ese momento no se podía vaticinar).

Sólo la segunda razón requiere alguna explicitación, por cuanto el autor de la tesis sostiene que, según aquella fórmula, el legislador ordinario, al formular el nuevo Código Civil, quedaba en libertad de mantener el divorcio o de abrogarlo. Semejante interpretación es, a nuestro entender, insostenible. Aquella fórmula sólo facultaba al legislador ordinario a establecer cuáles habrían de ser las causales del divorcio, y, por tanto, a aumentarlas - que, infortunadamente, es la tendencia universal y también en el Perú- o eventualmente a disminuirlas. El texto constitucional aprobado es muy claro al respecto: no se regula cuando se suprime... no cabe someter a reglas lo que no existe...

El autor de este artículo es consciente de que una recóndita razón que lo determinó a presentar aquella fórmula no ha de persuadir al señor Huapaya: la de que, católico de convicción como es y además de pública notoriedad, pensó que sería posible, con esa fórmula, devolver a la Iglesia una cierta presencia en la vida civil de los peruanos, acaso con una perspectiva de mayor vigencia en un futuro indeterminable. Al final de cuentas, no es de quienes separan su fe religiosa de su pensamiento jurídico ni de quienes se ruborizan de lo primero cuando expresan lo segundo.

\section{JUSTIFICACION Y CONSTITUCIONALIDAD DEL ARTICULO 316}

En parte por las consideraciones ya expuestas y en parte por las que luego se indicará, la crítica que el autor de la tesis dirige contra el proyectado art. 316 de la Comisión Reformadora del Código Civil es, en nuestro concepto, asaz infundada y deleznable.

Acaso conviene comenzar por precisar las razones que indujeron al autor de esta nota a proponerla, las cuales razones son:

a) La de que, habiendo sido obstruida la fórmula presentada a nivel de la Constituyente (la que inclúa a todas las formas religiosas), era forzoso procurar que al menos se aceptase otra menos amplia, no sólo para cumplir el mandato constitucional-que que- 
daría incumplido si sólo se admitiese una forma, la civil, de celebrarse el matrimonio-; y por consecuencia con la doble convicción del autor como jurista -que no se satisfizo con un rechazo sin expresión de motivos- y como católico - que entonces no tenía noticia, ni entonces le habría parecido verosímil que la hubiera, acerca de una oposición de la Iglesia Peruana.

b) La de que, siendo el Perú declarada y mayoritariamente católico y debiendo toda ley positiva inspirarse y dirigirse a la realidad sociológica concreta que pretende regir, la admisión de la forma canónica de celebración del matrimonio tenía plena justificación (consideración ésta que a nivel de la Constituyente fue preciso posponer en favor de una fórmula más extensa, para evitar la calificación de sectaria en una Asamblea no todos cuyos miembros eran católicos).

c) La necesidad de ahorrar a los contrayentes una gravosa e innecesaria duplicación de trámites y gastos, al obligárseles a casarse sucesivamente en forma civil y en forma religiosa (17).

d) La de poner fin al absurdo y la injusticia de que las parejas casadas sólo por la Iglesia siguieran siendo tenidas por la ley como cuncubinarias, con todas las consecuencias que ello implica. .

e) La de poner fin al abuso, registrado con alguna frecuencia en la práctica, de quienes contraen matrimonio canónico con una persona y matrimonio civil con otra, sin incurrir en un ilícito (18).

Modestas estas finalidades, en comparación con la de crear, junto al civil, otra clase de matrimonio, por las razones ya detalladamente expuestas, no dejaban de tener, sin embargo, una considerable importancia moral y legal.

(17) En promedio, el costo de un matrimonio civil es de unos $1 / .250 .00 \mathrm{y}$ el del religioso ( 1/. 220.00. En un pais de tan modesto ingreso per capita, esto explica muchos concubinatos y el éxito de los "matrimonios masivos" que organizan diversos concejos municipales.

(18) A estas razones, el autor de la tesis añade otra: la de que, según afirma, la Iglesia Católica es la única que tiene un verdade ro Derecho matrimonial. 
Pues bien, si se tiene en cuenta lo que se acaba de sintetizar, ninguna objeción cabe formular racionalmente contra el texto proyectado. Pero si se insiste -como insiste el autor de la tesis- en que la Constitución permite la instauración de varias clases de matrimonio sujetos a ordenamientos jurídicos diferentes y no sólo varias formas de celebrarlo-, entonces es posible, pero tozudo, formular todas las críticas que se contienen en la casi totalidad de la sección de la dicha tesis intitulada "El sistema matrimonial en el proyecto de la Comisión Reformadora".

En realidad, lo único que se ajusta a los hechos y al contenido y fundamento del texto proyectado es lo que se refiere a la "Forma de celebración" (Apartado B-3, p. 502), sobre todo en su primer párrafo y los siguientes párrafos incluidos bajo el epígrafe "E. Calificación y valoración del sistema": "La legislación y jurisdicción del Estado son las que regulan la institución matrimonial, y puestas así las cosas, no se podría hablar de dos institutos: matrimonio civil y matrimonio canónico. La concesión de efectos civiles al matrimonio religioso, celebrado con sujeción a los cánones de la Iglesia Católica, como manifestaba el art. 316 del proyecto, se reducía a la consideración de tal matrimonio como una simple forma de prestación del consentimiento matrimonial que, en lugar de manifestarlo ante el alcalde se declara ante el sacerdote. No se puede hablar, por tanto, de una dualidad de matrimonios sino de una única institución jurídica perfectamente definida: el matrimonio civil. Habrfa, pues, dos formas de celebrar el matrimonio civil: la forma civil y la forma religiosa".

No obstante, hemos de referirnos, en párrafos aparte, a tres cuestiones importantes, que por ello exigen refutación: la pretendida intromisión indebida del Estado en una esfera privativa de la Iglesia; las observaciones que se formula contra el proyectado requisito de inscripción del matrimonio canónicamente celebrado en el Registro Civil para que produjera efectos civiles; y la tacha que se formula contra el texto proyectado de ser atentatorio contra los principios constitucionales de libertad e igualdad religiosas y a-confesionalidad del Estado.

\section{a) Alegada intromisión del Estado en esfera de exc/usiva competencia de la Iglesia}


En términos conceptualmente confusos y bajo el título de "Competencia sobre las causas matrimoniales", el autor de la tesis sostiene: $1^{\circ}$, que, al regular el art. 316 el fondo juridico del matrimonio canónico violaba la competencia legislativa de la Iglesia; $2^{\circ}$, que, al guardar silencio sobre la separación, disolución y nulidad del matrimonio, quedaba claro, que el Estado pretendía asumir el conocimiento de las causas respectivas; $3^{\circ}$, que aceptar únicamente la forma y no tener en cuenta la restante regulación, era un atentado contra la libertad religiosa, y contra el mismo derecho de la Iglesia; y $4^{\circ}$, que es ilógico separar la parte sustantiva de la procesal del derecho.

Respóndase, acerca de lo primero, que el proyectado art. 316 jamás pretendió entrar a regular el fondo jurídico del matrimonio canónico; sobre lo segundo, que ese artículo no decía una palabra al respecto, pero es evidente que al Estado le correspondería conocer y resolver de esas causas, pues se referían a un matrimonio civil en todo su contenido (ya que sólo en las formalidades de la celebración se asumía la norma canónica); y acerca del cuarto, que, tratándose de una opinión del señor Huapaya, merece respeto como cualquiera otra, pero que no por ello es cierta.

En lo que atañe a la tercera afirmación -y también a la primera y la segunda- no habrá más remedio que repetir una vez más, y van cien, que el art. 316 jamás tuvo la intención de introducir en el Perú dos clases de matrimonios -porque ello habría ido más allá de lo que autoriza la Constitución-, sino únicamente aceptar dos formas de acceder a un solo matrimonio: la canónica y la civil. Y agregar que cuando un Estado soberano decide asumir -y aun copiar a la letra - una o muchas normas extranjeras y hasta un código entero, no comete ningún atropello (porque no hay en esto "derechos de autor"), sino que ejercita soberanamente su derecho de hacerlo; y que, en esa medida, incorporadas al Derecho nacional esa norma o conjunto de normas, se vuelven "sus" normas. De ello hay y sigue habiendo ejemplos por docenas; $y$ ello se explica por el valor intrínseco de las normas asumidas. Durante el siglo pasado, por ejemplo, Bélgica adoptó el Codigo Napoleón, Ecuador y Colombia, el de Chile, Japón gran parte del Código alemán, aun antes de que éste fuera promulgado; y el Perú adoptó, sucesivamente, los Códigos de Comercio de España y, hasta antes de la dación del primer Código Civil, incorporó a su Derecho sobe- 
rano normas de la metrópoli colonial y también del Derecho Canónico. Pero cuando esos Estados asumieron como suyas leyes extranjeras, nadie adujo que se apropiaban de lo ajeno, ni perdieron aquéllos la facultad de cambiarlas después en todo o en parte. y cuando asumieron sólo algunas normas de origen foráneo, nadie sostuvo que estaban violando la competencia legislativa ajena ni obligados a tomar el íntegro de aquellos ordenamientos.

No se pretendía, pues, invadir la esfera legislativa de la Iglesia, ni se trataba de una intromisión en ella del Estado. En otras palabras: si la pareja decidia efectuar la ceremonia de su casamiento ante la Iglesia, pero no inscribirlo en el Registro Civil, estaba casada para la Iglesia (y del todo sujeta a la regulación de ésta, sin intromisión alguna del poder civil) pero no para el Estado (situación que, en el fondo, se da ya desde 1930 en el Perú). Pero si decidía inscribirlo en el Registro Civil, además de estar casada para la Iglesia, (y para ella, por ejemplo, el matrimonio era indisoluble) pero también lo estaba para el Estado (y en este sentido enteramente sujeta al ordenamiento legal del Estado). El que esto pudiera causar confusión en los feligreses - que no engaño por parte del legislador - ello significa dos cosas: que la Iglesia deb fa esforzarse, por los medios a su alcance, para persuadir a los fieles a acatar las normas canónicas; y que el riesgo de confusión, emanada de una insuficiente formación o información de los católicos, constituía un inconveniente de orden práctico -como lo hizo notar el Episcopado- pero no un defecto de la ley civil.

Por último - aunque quizá muy importante-, el tema de la intromisión del Estado en la esfera de la Iglesia, mencionado por el autor de la tesis, obliga inevitablemente a recordar el riesgo contrario. Un hecho histórico viene a cuento a propósito de este delicado asunto; el de que, al mismo tiempo que el Estado peruano estudiaba y preparaba un nuevo Código Civil que sustituyese al de 1936, la Iglesia estudiaba y preparaba un nuevo Código de Derecho Canónico, en reemplazo del de 1917. Sería justo afirmar que el Estado Peruano habría incurrido en una inaceptable intromisión en la esfera privativa de la Iglesia si se hubiera permitido pedir o exigir el retiro de alguna de las normas proyectadas por ésta ¿Y qué habría, entonces, de afirmarse si se hubiera presentado el caso inverso? Pero ni se dio, por fortuna, el primer supuesto; ni, habiéndose dado el segundo, piensa el autor de esta nota que hubo 
violación o intromisión indebida. Cree, eso sí, que el mismo resultado y aun más rápidamente pudo haberse obtenido a nivel del mismo ponente del Libro, sin el riesgo de introducir un innecesario ingrediente de adustez, fclizmente momentánea, en las relaciones tradicionalmente cordiales entre la lglesia y el Estado en el Perú.

\section{b) El requisito de la inscripción del matrimonio canónico en el Registro del Estado Civil}

El autor de la tesis plantea al respecto las siguientes objeciones:

1. Que la fórmula propuesta "parece indicar que la inscripción es la conditio juris para la producción de efectos civiles, lo cual estaría en contradicción con la primera parte (del mismo artículo 316) en la que el término produce referido al matrimonio religioso significa que el origen de los efectos civiles no es la ley estatal sino el matrimonio celebrado"; y que "una fórmula más acertada hubiera sido la siguiente: El matrimonio religioso produce efectos civiles. Para el reconocimiento de los mismos es necesario que se inscriba en el registro del estado civil".

No, no es que la fórmula parezca indicar que la inscripción sea condición esencial para que el matrimonio religioso produzca efectos civiles: es eso lo que indica -y muy claramente por cierto- la fórmula del art. 316 . Y no hay ninguna contradicción entre las dos partes de ella; como nadie podría válidamente encontrar contradicción en la ley cuando, por ejemplo, acoge una figura y acto seguido -en el mismo artículo o en otro-- sujeta su validez o condiciona sus efectos a la inscripción en un registro público (arts. 1097 sobre la hipoteca, 496 sobre patrimonio familiar...); y en otro plano admite la condición suspensiva de los efectos de un acto juridico con la generalidad en que lo hacen los arts. $171 \mathrm{y}$ ss. del nuevo texto civil.

En cuanto a si la fórmula más apropiada es la que se utilizó en cl proyectado art. 316 o la que sugiere el autor de la tesis, es pertinente recordar que, por ejemplo, el Código de 1852, declaró en un artículo (156) que el matrimonio se celebraba con las formalidades del Concilio de Trento, en otro (441) exigió el asentamiento de la partida en el Registro Civil, y luego, en el 443, preceptuó 
que "para reclamar los efectos civiles anexos al matrimonio... (debía acompañarse) el certificado de la partida del Registro. El Código de 1936 utilizó otra fórmula: "No producirá efectos civiles el matrimonio celebrado conforme al art... 120 (in extremis) mientras no se inscriba en el Registro Civil" (art. 126) (En ninguno de cuyos casos, que sepamos, estimó nadie que esa exigencia atentaba contra nada).

¿Por qué la fórmula empleada en el proyectado art. 316 habría de ser menos técnica que la que propone el autor de la tesis?

Parece ser, por lo demás, que éste padece una cierta confusión: una cosa es la partida de matrimonio (que es un acta extendida en el Registro del Estado Civil, que integra las formalidades esenciales de la celebración del casamiento y que nadie puede extraer de alli sin incurrir en delito); y otra, el certificado de esa partida, que es una copia auténtica de ésta y que puede ser obtenida cuantas veces sea necesaria (el cual sirve para acreditar, dentro de juicio o fuera de él, el hecho del matrimonio). La primera se sitúa en el plano de lo esencial -y por eso se ocupa de ella el Código Civil-; lo segundo, en el de lo adjetivo (y por ello se ocupan de ello los reglamentos o el texto procesal).

2. Que el requisito esencial de la inscripción en el registro del estado civil "no dejaba de ser una evidente intromisión de normas civiles en el momento registral".

Sin parar mientes en cuestiones como la de saber a quién compete precisar el lindero que separa el campo de la ley civil del "momento registral" o si la intromisión parecería más pertinente cuando una norma inferior incursiona en la esfera propia de otra superior, importa, sí, señalar que cuando la inscripción en un registro público viene exigida como requisito ad sustantiam, del cual, por tanto, depende la validez $-\mathrm{y}$, en consecuencia, la producción de efectos- de un acto jurídico, o cuando se trata de actos jurídicos inscribibles, entonces es la ley civil, la ley sustantiva a la que corresponde preceptuarlo, en tanto que la implementación de esa norma para asegurar su operancia y cumplimiento es materia que corresponde a los reglamentos del respectivo registro. $\mathrm{Y}$ así es, en efecto, como ocurre en todo nuestro ordenamiento legal: el Código Civil exige la inscripción de actos jurídicos (como el matrimonio, precisamente), la autoriza en muchos otros; y dedica a la ma- 
teria, no sólo un Título integro para los registros del estado civil, sino todo un Libro, el IX, compuesto de ocho Títulos a los demás registros públicos, sin perjuicio de la implementación de detalle que es materia de las reglamentaciones de todos esos registros.

3. Que existía "pobreza legislativa" en el artículo propuesto pues no precisaba quiénes podían pedir la inscripción, a quién correspondía remitir la partida sacramental, dentro de qué plazos... etc.

A esta objeciôn es forzoso responder con dos argumentos: el de que hay contradicción entre ésta y la objeción anterior, y el de que la determinación de aquellos puntos era más propia del reglamento (que, por cierto, no llegó a darse, porque la fórmula fue retirada a pedido del Episcopado). Sólo el primero necesita alguna explicitación: la contradicción en que incurre el autor de la tesis nos parece flagrante: había sostenido que el proyectado art. 316 invad fa el momento registral, o sea, que decía demasiado; y ahora sostiene que, por el contrario, le faltaba decir mucho.

4. Finalmente, que, al otorgarse a la mencionada inscripción una virtualidad suspensiva de los efectos civiles del matrimonio religioso, "la inscripción hubiera dejado de cumplir las funciones que le son propias, entre las cuales hay que señalar principalmente: a) Dejar constancia oficial de la celebración... y b) Procurar la armonía entre los ordenamientos canónico y civil...".

Es claro que las dos funciones que el autor de la tesis atribuye a la inscripción ni son las únicas -él mismo dice que son sólo las principales-; que la segunda de ellas representa el punto de vista, sin duda respetable, pero no infalible, del autor de la idea; y que nadie ni nadie impide a la ley peruana el derecho de atribuirle, como se buscaba en este caso concreto, una función aun más importante: la de conferir validez y reconocer efectos civiles al matrimonio canónico.

\section{c) El pretenso atentado contra la libertad e igualdad religio- sas y la aconfesionalidad del Estado}

Invocando el art. $2,3^{\circ}$ de la Constitución, el autor de la tesis sostiene que "la verdadera tutela del derecho fundamental de libertad de conciencia y de religión... supone que el Estado está llama- 
do a reconocer el derecho subjetivo a contraer matrimonio canónico con efectos legales y a reconocer, asimismo, con auténtica tutela jurídica, la opción que haga cualquier ciudadano de contraer matrimonio según su conciencia..." principio éste que "está en conexión con el art. 5 ("las formas de matrimonio... son requladas por la ley") "con la única limitación de que no se altere el orden público" (19).

De ser correcta la interpretación que se hace del art. $2,3^{\circ}$ de la Carta y teniendo muy en cuenta que, como se ha expresado ya, la expresión formas de matrimonio... equivale, según el señor Huapaya, a clases de matrimonio (cada una de ellas con su propio régimen jurídico), resultaría que toda persona puede, no sólo casarse según las formalidades o ritos de su confesión religiosa, sino que las normas que ésta tenga rijan la integridad del estado matrimonial (efectos, decaimiento, eventual disolución).

Ya nos referimos, y por tanto, no repetiremos, al desbarajuste que ocasionaría semejante heterogeneidad (en la que podría comprenderse regímenes que autorizan el repudio de cualquiera de los cónyuges contra el otro, el convenio de hacerse esterilizar $u$ otros semejantes... ).

Por cierto que el autor de la tesis sale, un poco superficialmente, al encuentro de la objeción al sostener que el Estado, invocando el orden público - lo que, en principio, es aceptable-pueda reconocer o autorizar a unas confesiones y no a otras. ¿No se diría entonces, que el Estado esta discriminando, persiguiendo a unas y amparando a otras y atropellando el principio de la libertad religiosa tal como lo entiende el autor de la tesis?

Además, ¿qué órgano del Poder Público ha recibido de la Constitución la facultad de decidir cuándo se afecta el orden pú-

(19) Como es sabido -e infortunadamente - la expresión "orden público" suele usarse en dos alcances entre los que media una abismal diferencia de contenido y trascendencia: como el conjunto organico de principios y no mas fundamentales sobre el que se construye y que enmarca todo el orden social; y como sinónimo de la tranquilidad callejera, susceptible de ser turbada por alborotadores inciviles. No obstante que los términos en que el autor de la tesis alude al orden público pudieran conducir a la impresión de que piensa en la segunda y subalterna acepcion, debe suponerse que se refiere a la primera. 
blico: acaso el Ejecutivo, por decreto, o el Legislativo por ley, o el Judicial por sentencia? ¿Acaso el Tribunal de Garantías...? ¿Y no se podria argüir, aun entonces, por la confesión afectada, que ese Poder u órgano está violando el principio de libertad religiosa, que, según el señor Huapaya, supone que el Estado está llamado a reconocer el derecho subjetivo de cada persona a contraer matrimonio según su conciencia?

De otro lado, el autor de la tesis extrae de la proclamación constitucional referente a la libertad de conciencia y de religión la conclusión de que ello obliga a tratar por igual a todas las confesiones. Pues bien, la Constitución de 1933 contenia en su art. 59 exactamente la misma proclamación, lo que no impidió que en el art. 232 declarara que el Estado protege a la Religión Católica, Apostólica y Romana. ¿Violó con esta última norma el principio proclamado en la primera? ¿Protestó la lglesia por ello? Ciertamente no, en virtud de una consideración de indole sociológica que el autor de la tesis a veces apoya y a veces rechaza: la de ser católica la mayoria de la población: así, expresamente, lo indica el art. 232; y es perfectamente justificado que asi sea, porque se legisla para un país determinado y es forzoso tener en cuenta sus peculiaridades. Pues... ésta fue precisamente la razón -o una de las razones-que justifican la fórmula del propuesto art. 316 , que el señor Huapaya combate.

El verdadero alcance de la norma constitucional consiste en que todos tienen derecho a profesar las creencias, elegir la confesión religiosa o no elegir ninguna, sin que puedan ser perseguidos o acosados o discriminados por ese motivo; y la norma propuesta no lo hacía ni lo propiciaba. A nadie se le obligaba por ella a casarse en forma canónica, ni a inscribir ese matrimonio en el registro del estado civil.

Pregúntese, en fin, llevando el argumento hasta sus consecuencias finales: ¿para quién legislaría el Estado en materia matrimonial, si cada confesión religiosa tuviese el derecho de dictar su propio ordenamiento (20) ¿Solamente para los ateos? Y, al no

(20) El autor de la tesis afirma que sólo la Religión Católica, la hebrea y la islámica tienen un Derecho matrimonial. Hacemos plena fe en su afirmación; pero ello no autoriza a suponer que en el futuro otras confesiones no se darản el suyo. 
recurrir éstos al régimen matrimonial de ninguna confesión, ¿estarían así declarando ser ateos? ¿Y la privacidad de las convicciones en materia religiosa, que también constituye una proclamación constitucional?

La tesis del señor Huapaya podría conducir, por vía lógica, a una situación en que el Estado Nacional abdicara de regular el matrimonio y trasfiriera esa atribución a las distintas confesiones. ¿Es que el fenómeno matrimonial carece de importancia para el Estado, es un asunto exclusivamente encerrado en la conciencia de cada quien? ¿Por qué, entonces, habría de haber proclamado la misma Carta que el Estado protege el matrimonio y la familia?

Preguntas como éstas se contestan por sí solas. Acaso se deba añadir una sola consideración más: el art. 86 de la Carta declara que "dentro de un régimen de independencia y autonomía, el Estado reconoce a la Iglesia Católica como elemento importante... etc." (y acierta al reconocerlo, sin que con ello discrimine en contra de otras confesiones, que no han jugado el mismo papel en la formación histórica, cultural y moral del Perú, lo cual es un factor sociológico que no se puede ignorar al legislar a nivel de la Constitución y de la ley civil u otra); pero autonom ía significa auto-normarse, dictar sus propias normas... ¿Se cumpliría este mandato si el Estado entregara a cada confesión religiosa la facultad de normar el matrimonio de sus miembros o fieles?

Otra observación cabría formular acerca de la libertad religiosa si ella implicase el derecho de cada confesión a normar el matrimonio de sus fieles. ¿Qué ocurriría si, después de casados, cambiaran de religión, en ejercicio de su libertad de conciencia y religión? ¿Qué régimen se aplicaría en adelante acerca del contenido, el decaimiento o eventual disolución del matrimonio? ¿Y si sólo uno de los cónyuges mudara de religión?

Varios de los argumentos reseñados valen también para impugnar la tesis del señor Huapaya en el sentido de que la propuesta norma 316 violaba el principio de la igualdad religiosa. Se puede, además recordar que el Código Civil de 1936 concedió a la confesión católica tres atribuciones que no extendió a ninguna otra confesión: la de que el matrimonio de urgencia pudiera ser celebrado ante un sacerdote $-\mathrm{y}$ con las formalidades canónicas, según la in- 
terpretación común, esta vez si, al autor de la tesis y al de esta nota- (art. 120); la de poder los misioneros católicos y capellanes de hospitales celebrar el casamiento civil por delegación del alcalde (art. 115); y la de autorizar al Obispo o al párroco para celebrar el matrimonio civil o facultar para ello a otro sacerdote (art. 124); obvia "discriminación", en concepto del señor Huapaya, que acaso pudiera justificar éste recordando que la Constitución de 1933 declaraba la protección de la Iglesia Católica por el Estado, pero que apareceria injustificada desde que, en 1948, el Perú suscribió primero la Declaración Americana de los Derechos y Deberes del Hombre, y luego la Declaración Universal de los Derechos Humanos, las cuales prohiben la discriminación en sus arts. II y 1,2 y 3 , respectivamente.

$\mathrm{El}$ art. $2,2^{\circ}$ de la Carta prohibe toda discriminación por razón de la raza o el idioma. ¿Se violará a sí misma cuando en el art. 83 declara que el castellano es el idioma oficial de la República, en tanto que el quechua y el aymara son sólo lenguas de uso oficial, las demás lenguas aborígenes integran el patrimonio cultural de la Nación, y del chino o el alemán que hablan ciertos núcleos minimos de peruanos no dice nada? ¿Atraerá la oposicion del autor de la tesis el pedido que hizo el Episcopado Peruano al Ministro de Justicia, por oficio de fecha 8 de mayo de 1981 para que "en la Selva permanezcan las facultades para la celebración de matrimonio que tienen los Misioneros Católicos... en vista de la peculiar situación allí existente, y conceder el permiso para los matrimonios de menores en las poblaciones alejadas de los centros distritales? ¿Se desautorizará a si mismo el autor de la tesis cuando, al tratar de la facultad que se concede al párroco o al Ordinario del lugar para celebrar la ceremonia del matrimonio civil de sus fieles, la justifica diciendo que "se debe al reconocimiento de las convicciones religiosas de la mayoría de los peruanos y a la formación histórica, cultural y moral de nuestro pais?

Ciertamente ni la Constitución se negó a sí misma cuando "discriminó" el chino o el alemán al no declararlos idiomas oficiales, ni atentó el Episcopado contra el principio constitucional de la igualdad religiosa cuando pidió que los misioneros católicos en la Selva tuvieran ciertas facultades o que las tuvieran en las poblaciones alejadas de los centros distritales; ni se niega a sí mismo el señor Huapaya cuando justifica el mantenimiento de la facultad 
del párroco o el Ordinario para celebrar la ceremonia del matrimonio civil de sus fieles. Lo que ocurre es que, como hemos ya dicho, la Constitución -aquí o en cualquier otro país- no se reduce a una declaración teórica de los grandes principios, sino que pretende fijar el cuadro fundamental dentro del que debe "vivir" una comunidad de hombres y mujeres concretos; por lo cual es forzoso que tenga muy en cuenta las caracteristicas sociológicas que lo tipifican (raza, idioma, religión....). De lo contrario, legislaría utópicamente para un "país ideal". Entonces, todos los países podrían tener una sola Constitución: al menos todos los que suscriben los mismos grandes principios. No es así, obviamente, porque cada pais tiene su propia realidad, sus características tipificantes y la Constitución $-\mathrm{y}$ las leyes civiles o de otra índole - no traicionan su papel si las tienen en cuenta: faltarían a èl si no las consideraran.

Cree el autor de esta nota que le asistía la razón cuando sostenía, al nivel de la Asamblea Constituyente, que ni había discriminación en hacer notar que la mayoría del Perú es católica y que el mencionarlo no se debía a consideraciones religiosas sino sociológicas (lo que es decir que, aunque el autor de esta nota no fuera católico, que lo es y al menos aquí nadie lo ignora, sino budista, habría defendido lo que luego habría de ser el texto del proyectado artículo 316; o que, si él fuese católico, pero la mayoría hubiera sido islámiça, habría sostenido la misma tesis en favor de esa confesión religiosa en cuanto factor histórico o sociológico).

Dígase, en fin, que tampoco se violaba con esa propuesta el art. 5 de la Carta, pues éste no manda que la ley regule todas las formas de matrimonio. No incluye la palabra subrayada. Dice simplemente en plural las formas y el plural comienza -y puede quedarse - en dos, que son las que proponía el autor del tantas veces aludido art. 316 .

Otras apreciaciones y opiniones existen en la tesis del señor Huapaya que, en el modesto concepto de quien suscribe la presente nota-comentario, están equivocadas o son inexactas; mas ni ellas son materia del comentario que termino, ni ellas, ni las que se ha comentado, privan al autor de la tesis del mérito de su trabajo, del esforzado empeño con que la ha elaborado y de la buena intención que lo ha guiado al concebirla y redactarla; todo lo cual justifica que nuestra palabra final sea de aprecio y agradecimiento. 